\title{
GLOBAL HÖLDER SOLUTIONS FOR ABSTRACT NEUTRAL FUNCTIONAL DIFFERENTIAL EQUATIONS
}

\author{
EDUARDO HERNÁNDEZ
}

Abstract. We study the existence of global $\alpha$-Hölder mild solutions and $S$-classical solutions for a class of abstract neutral functional differential equations defined on whole the real axis. Some concrete applications to ordinary and partial differential equations are considered.

Mathematics subject classification (2010): 35R10, 34K40, 34K30.

Keywords and phrases: neutral equations, mild solutions, classical solutions.

\section{REFERENCES}

[1] M. Adimy AND K. EzZINBI, A class of linear partial neutral functional-differential equations with nondense domain, J. Diff. Eqns., 147, 2 (1998), 285-332.

[2] P. CANNARSA AND D. SFORZA, Global solutions of abstract semilinear parabolic equations with memory terms, NoDEA Nonlinear Differential Equations. Appl., 10, 4 (2003), 399-430.

[3] E. N. CHUKWU, Differential models and neutral systems for controlling the wealth of nations, Series on Advances in Mathematics for Applied Sciences, 54. World Scientific Publishing Co., Inc., River Edge, NJ, 2001.

[4] Ph. Clément And J. A. Nohel, Asymptotic behavior of solutions of nonlinear Volterra equations with completely positive kernels, SIAM J. Math. Anal., 12, 4 (1981), 514-535.

[5] P. Clément AND J. PRÜSS Global existence for a semilinear parabolic Volterra equation, Math. Z., 209, 1 (1992), 17-26.

[6] M.E. GURTIN AND A.C. PIPKIN, A general theory of heat conduction with finite wave speed, Arch. Rat. Mech. Anal., 31 (1968), 113-126.

[7] J. K. HALE AND VerdUyn LunEL, Introduction to functional-differential equations, Applied Mathematical Sciences, 99, Springer-Verlag, New York, 1993.

[8] J. K. Hale, Partial neutral functional-differential equations, Rev. Roumaine Math. Pures Appl., 39, 4 (1994), 339-344.

[9] E. HeRnÁNDEZ AND H. Henríluez, Existence results for partial neutral functional differential equation with unbounded delay, J. Math. Anal. Appl., 221, 2 (1998), 452-475.

[10] E. HERNÁNDEZ AND D. O'REGAN, Existence results for abstract partial neutral differential equations, Proc. Amer. Math. Soc., 137 (2009), 3309-3318.

[11] E. HERnÁNDEZ, Existence results for partial neutral integrodifferential equations with unbounded delay, J. Math. Anal. Appl., 292, 1 (2004), 194-210.

[12] E. HERNÁNDEZ, Existence results for a class of semi-linear evolution equations, Electron. J. Differential Equations, 2001, 24 (2001), 1-14.

[13] E. HERNÁNDEZ AND H. HENRÍQueZ, Existence of periodic solution of partial neutral functional differential equation with unbounded delay, J. Math. Anal. Appl., 221, 2 (1998), 499-522.

[14] Y. Hino, S. MuraKami And T. NAito, Functional-differential equations with infinite delay, Lecture Notes in Mathematics, 1473, Springer-Verlag, Berlin, 1991.

[15] A. LunARDI, On the linear heat equation with fading memory, SIAM J. Math. Anal., 21, 5 (1990), $1213-1224$.

[16] A. LunARDi, Analytic Semigroups and Optimal Regularity in Parabolic Problems, Birkhäuser, Berlin, 1995. 
[17] J. W. NunZIATO, On heat conduction in materials with memory, Quart. Appl. Math., 29 (1971), $187-204$.

[18] J. WU AND H. XIA, Rotating waves in neutral partial functional-differential equations, J. Dynam. Differential Equations, 11, 2 (1999), 209-238.

[19] J. WU AND H. XIA, Self-sustained oscillations in a ring array of coupled lossless transmission lines, J. Differential Equations, 124, 1 (1996), 247-278.

[20] J. WU, Theory and applications of partial functional-differential equations, Applied Mathematical Sciences, 119, Springer-Verlag, New York, 1996. 